\title{
Cellular-Based Immunotherapies for Patients with Glioblastoma Multiforme
}

\author{
Xun Xu, ${ }^{1}$ Florian Stockhammer, ${ }^{2}$ and Michael Schmitt ${ }^{3}$ \\ ${ }^{1}$ Center for Biomaterial Development and Berlin-Brandenburg Center for Regenerative Therapies, Institute of Polymer Research, \\ Helmholtz-Zentrum Geesthacht, 14513 Teltow, Germany \\ ${ }^{2}$ Department of Neurosurgery, University of Göttingen, 37073 Göttingen, Germany \\ ${ }^{3}$ Department of Internal Medicine V, Hematology, Oncology and Rheumatology, University of Heidelberg, 69120 Heidelberg, Germany
}

Correspondence should be addressed to Michael Schmitt, michael.schmitt@med.uni-heidelberg.de

Received 7 November 2011; Accepted 8 December 2011

Academic Editor: Luca Gattinoni

Copyright () 2012 Xun Xu et al. This is an open access article distributed under the Creative Commons Attribution License, which permits unrestricted use, distribution, and reproduction in any medium, provided the original work is properly cited.

\begin{abstract}
Treatment of patients with glioblastoma multiforme (GBM) remains to be a challenge with a median survival of 14.6 months following diagnosis. Standard treatment options include surgery, radiation therapy, and systemic chemotherapy with temozolomide. Despite the fact that the brain constitutes an immunoprivileged site, recent observations after immunotherapies with lysate from autologous tumor cells pulsed on dendritic cells (DCs), peptides, protein, messenger RNA, and cytokines suggest an immunological and even clinical response from immunotherapies. Given this plethora of immunomodulatory therapies, this paper gives a structure overview of the state-of-the art in the field. Particular emphasis was also put on immunogenic antigens as potential targets for a more specific stimulation of the immune system against GBM.
\end{abstract}

\section{Introduction}

The primary brain tumor, glioblastoma multiforme (GBM), occurs in 3 to 4 adult patients per 100,000 inhabitants in Europe, thus being the most common and life threatening primary brain tumor [1]. GBM is invasive and infiltrates the surrounding brain tissue.

GBM is most common in adults older than 50 years and affects more men than women. Furthermore, around 9\% of childhood brain tumors are GBMs. The median survival from the time of diagnosis without any treatment is 3 months. The major prognostic factors are age and Karnofsky performance status (KPS) at the time of diagnosis [2].

\section{Standard Treatment of Glioblastoma (GBM)}

2.1. Primary Treatment. Although GBM has a typical appearance in MRI, histological diagnosis is mandatory for proper diagnosis. A treatment option is gross tumor resection (GTR), which involves the contrast enhancing tumor in to the MRI without causing additional neurological deficit [3]. The extent of resection can be optimized using fluorescence-guided resection [4], which probably includes noncontrast enhancing tumor part and can be visualized by aminoacid positron emission tomography [5]. Placing carmustine-loaded wafers in the resection cavity has shown to prolong survival rates [6]. However, the clinical benefit seems to be limited to patients with GTR and good KPS [7]. If GTR cannot be achieved and the tumor mass does not cause a midline shift, stereotactic serial biopsy is a safe procedure to enable histological and genetic diagnosis [8-10].

Following surgery, a typical treatment consists of concomitant temozolomide and $60 \mathrm{~Gy}$ radiotherapy of the tumor region for six weeks followed by 6 adjuvant cycles of temozolomide $[11,12]$. After applying this treatment, tumors with methylated promotor for $\mathrm{O}(6)$-methyl-guanine DNA methyltransferase (MGMT) appear to have a favorable clinical course with a median overall survival of 21.7 months [13].

Although long-term adjuvant temozolomide is safe [14], there is no evidence that the continuation of temozolomide beyond six cycles gives any additional benefit.

2.2. Recurrent GBM. In recurrent GBM, surgery is an optional treatment. However, there is no evidence for the clinical benefit of second surgery. According to retrospective 
studies, a second resection should be restricted to patients with good KPS and feasible systemic salvage treatment [15, 16]. Alternatively, conformal reirradiation may be administrable $[17,18]$.

For systemic treatment of recurrent glioblastoma, bevacizumab is FDA approved but only with class 2 evidence [1922]. In Europe, bevacizumab remains off-label treatment for glioblastoma patients. Rechallenge with TMZ is an alternative to bevacizumab. Thereby, protocols vary from doseintensified treatment to metronomic schedules [23-26]. However, there are no positive randomized controlled trials defining a standard treatment in recurrent glioblastoma. However, salvage treatment should be applied as long as the patient's condition has not declined [27].

Due to the limited treatment options for GBM patients, there is a fervent need for novel therapies such as immunotherapies. However, the brain is known as one of the immunologically privileged sites and is able to tolerate the introduction of antigen without eliciting an inflammatory immune response [28]. Thus, immunotherapy for brain tumor seems to constitute a "mission impossible." Fortunately, it is now known that the central nervous system at least maintains a reciprocal communication network with the immune system. Infectious or experimental autoimmune encephalomyelitis animal models allow us to understand better how the immune system operates in the brain [29]. Therefore, immunotherapy offers the opportunity to allow the patient's immune system a chance to eliminate the tumor. The strength of immunotherapy with DCs has been demonstrated on the Food and Drug Administration (FDA) approval of DCs as "Provenge" for prostate cancer [30]. As for GBM, it has been demonstrated that it efficiently treats relatively small tumors in experimental animal models.

This paper focuses on the cellular-based immunotherapy for brain cancers with emphasis on GBM. We will also highlight some of the possible directions that may be taken in the immediate future to improve this therapeutic option.

\section{Immunotherapy}

There are two important basic strategies for immunotherapy. Firstly, adoptive immunotherapy, which means the passive administration of sensitized immune cells to patients. Secondly, the strategy of "active immunotherapy" is based on the boosting of antitumor T-cell responses by antigenpresenting cells (APCs), especially by dendritic cells (DCs).

3.1. Adoptive Immunotherapy. In adoptive immunotherapy, in vitro activated immune cells are administered to tumorbearing patients. Lymphokine-activated killer (LAK) cells, which were generally obtained by cultivating peripheral lymphocytes in the presence of T-cell growth factor interleukin2 (IL-2) and other cytokines. These LAKs showed cytolytic properties but not specifically against tumor cells [31-42]. A novel therapeutic option was to collect lymphocytes from lymph nodes or peripheral blood mononuclear cells (PBMCs) after peripheral injection of irradiated autologous tumor cells and granulocyte-macrophage colony-stimulating factor (GM-CSF), stimulating them in vitro, and subsequently reinjecting them [43-47]. Allogeneic cytotoxic T lymphocytes (CTLs) stimulated by the patient's autologous lymphocytes have been tested for recurrent GBM as well [48]. They were generated by ex vivo antigenic stimulation of PBMCs. As Quattrocchi et al. have shown in a pilot study, CTLs can also be amplificated from tumor-infiltrating lymphocytes (TILs) in the presence of IL-2 [49].

Injection of CTLs or TILs appeared to allow higher objective responses compared to LAKs in some GBM patients. Due to the large variability observed between patients and the limited number of patients, the correlation between the number of effector cells, their cytotoxic activity, and the clinical outcome is still not clear. Kronik et al. have predicted that GBM would be eradicated by new dose-intensive strategies, for instance, $3 \times 10^{8}$ CTLs every 4 days for small tumor burden or $2 \times 10^{9}$ CTLs infused every 5 days for larger tumor burden [50]. Interestingly, in several clinical trials with LAK and CTL therapy, the eosinophilic infiltration at the tumor site and in cerebrospinal fluid (CSF) could be observed [38, 40, 48, 49]. The impact of chemotherapy or corticosteroids on the efficacy of the treatment might also be questioned. These drugs were completely avoided in some trials according to their immunosuppressive properties $[31,39,41,42]$; however, other studies have shown no influence of steroids or chemotherapy on the stimulation and the cytotoxic activity of the effector cells $[32,34,35]$.

Progress in the treatment of brain tumors using immunotherapy is slowly moving forward. Initial attempts used nonspecific approaches, like adjuvants and, LAK cells were only minimally effective. Nowadays, the general focus is directed towards specific cellular approaches including TILs and CTLs, and alloreactive CTL stimulated by mixed lymphocyte reactions. All of these approaches have yielded some clinical success. GBM cells seem to have a plethora of tumorassociated antigens. Active immunization with autologous DCs that have been loaded with tumorantigens also appear to generate long-term survivors. Identification of other strategies that can be combined with immunotherapy approaches might improve our success against GBM.

\subsection{Active Immunotherapy}

3.2.1. Active Immunotherapy in GBM Using Autologous Tumor Cells (ATCs). Autologous tumor cells are removed from patients during surgery. Whole cells, parts of cells, or antigens can be used to create a vaccine to a specific tumor. To date, there are at least eight high qualified trials, which focused on the GBM treatment were reported [51-58]. One phase I clinical trial [58], two cases report [51, 54], and five pilot studies of antitumor vaccination [52, 53, 55-57] were included, and the vaccination was repeated in all of these studies. ATCs are generally inactivated by radiation, sometimes genetically modified $[51,54,56]$, and could be infected with a virus $[52,55]$ to enhance the immune response. The strategy of using antisense oligonucleotides for insulin growth factor receptor 1 for ATCs prior to implantation was applied in one pilot study [53]. The cells were injected either subcutaneously or intradermally. In three 


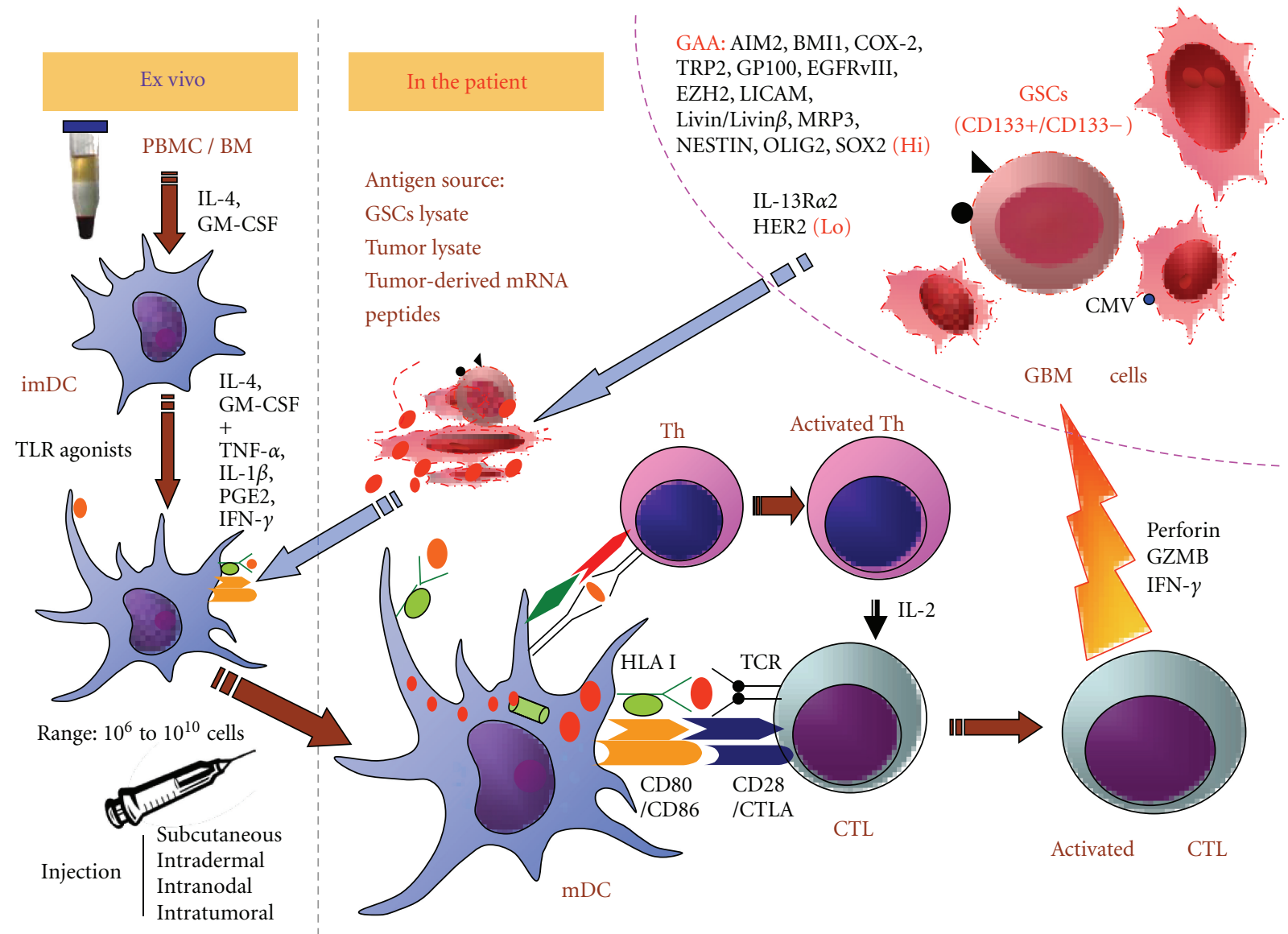

FIGURE 1: DC-based active immunotherapy for GBM. DCs display a unique capacity to induce and to maintain T-cell responses. Mature DCs are generated from PBMC in vitro in the presence of IL-4, GM-CSF, TNF-alpha, IL-1beta, PGE2, IFN-gamma, and other cytokines, in addition to TLR agonists. Subsequently, they are loaded with GBM or glioblastoma stem cell lysates, GBM-associated antigen-derived peptides, protein, or RNA. Due to their high surface expression of HLA-peptide-complexes and costimulatory molecules, DCs could efficiently activate and expand CD8 ${ }^{+}$CTLs and $\mathrm{CD}^{+}{ }^{+}$Th cells. CD8 ${ }^{+}$CTLs are able to recognize and eliminate tumor cells, especially the GBM stem cells (CD133). CD4 ${ }^{+}$Th cells enhance the capacity of DCs to induce CTLs by the interaction between CD40 on DCs and CD40 ligand on activated CD4 ${ }^{+} \mathrm{T}$ cells. In addition, $\mathrm{CD} 4^{+} \mathrm{T}$ cells help in the maintenance and expansion of CTLs by secreting IL-2. CTLs: cytotoxic T cells; imDC: immature dendritic cells; GZMB: granzyme B; GSCs: glioblastoma stem cells, HLA: human leukocyte antigen; IL: interleukin; IFN: interferon; mDC: mature dendritic cells; PBMC: peripheral blood mononuclear cells; TCR: T-cell receptor; Th: T helper cell; TLR: toll-like receptor.

studies, injections of ATCs were given concomitantly with IL-2 [51], IL-4 [54] or B7-2, and GM-CSF infusions [56]. Different amounts of cells were given for vaccination.

At least half of the patients in these studies showed an induction of immune responses both in peripheral blood and tumor site $[53,55]$. Toxicity was addressed in all trials without any severe adverse events. Beside an immune response, a clinical response was demonstrated to be associated with survival benefit in five studies with three complete responses (CRs), four partial responses (PRs), two minor responses (MRs), and six stable diseases (SDs) in a total of $48 \mathrm{GBM}$ patients [53-55, 57, 58].

\subsubsection{Active Immunotherapy Using Dendritic Cells. Dendritic} cells (DCs) are professional antigen-presenting cells (APCs), which play a key role in eliciting, maintaining, and regulating T-cell responses $[59,60]$. DCs are present in almost all organs, even in immune-privileged sites such as the central nervous system, testis, and ovaries. DCs can be generated not only from lymphoid organs but also from the blood or lymph. DC vaccines are attractive and now widely used in GBM active immunotherapy based on their various antitumor effects (Figure 1).

In Table 1, we summarized 15 clinical trials reported so far including 316 patients [61-75]: eight phase I trials [62, $64,65,69-72,75]$, six phase I/II trials [61, 63, 66, 68, 73, 74], and one phase II trial [67]. Monocyte-derived DCs were used for most of the clinical trials. The preparation of DC is now well established, and a sufficient number of DC can be generated for injections into patients [76, 77]. Immature DCs were widely used in older trials $[67,69,70,74,75]$; however, some trials have used maturation factors like TNFalpha [71], toll-like receptor (TLR) agonists: penicillin-killed streptococcus pyogenes (OK-432) [68] and imiquimod [62, 


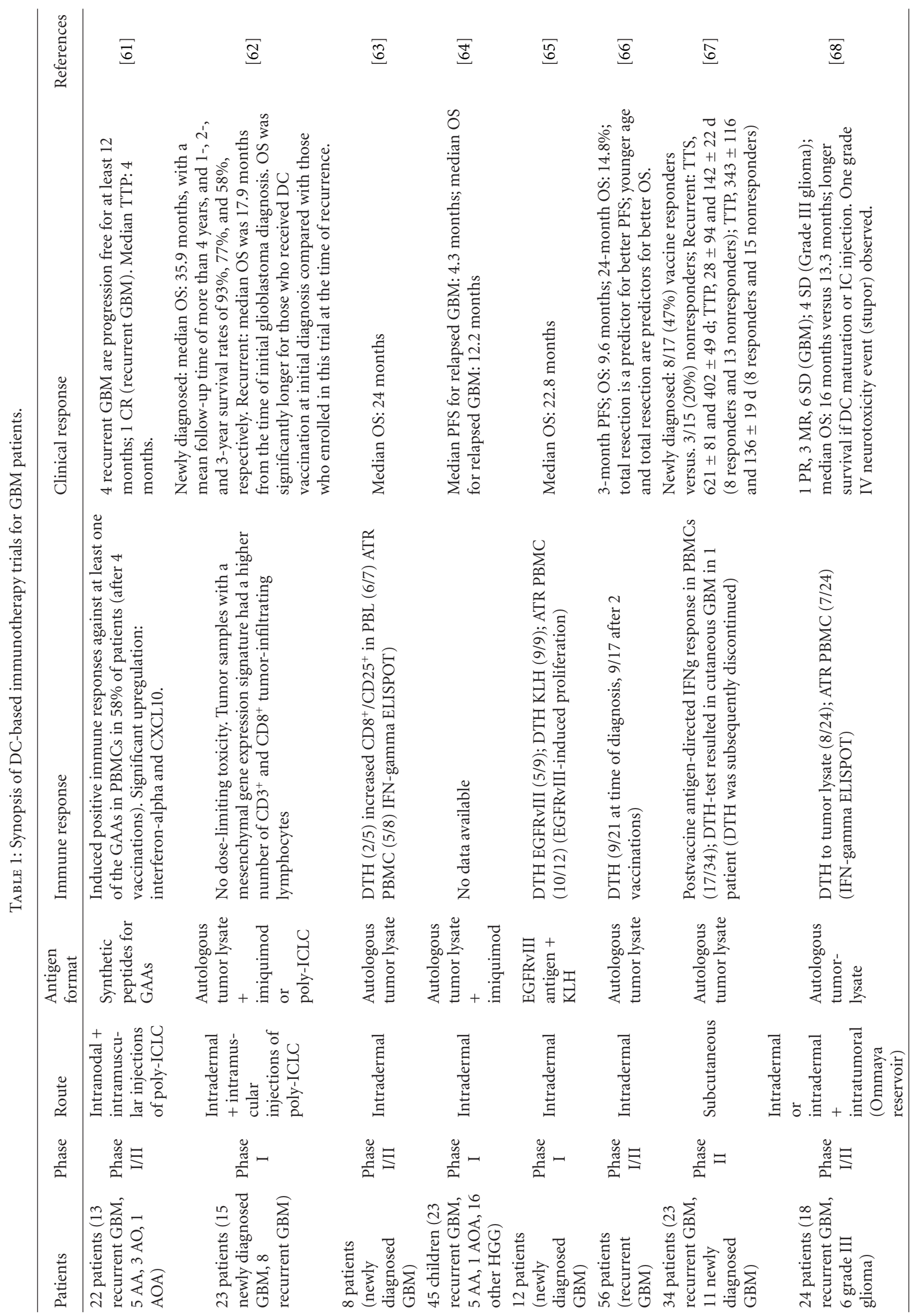




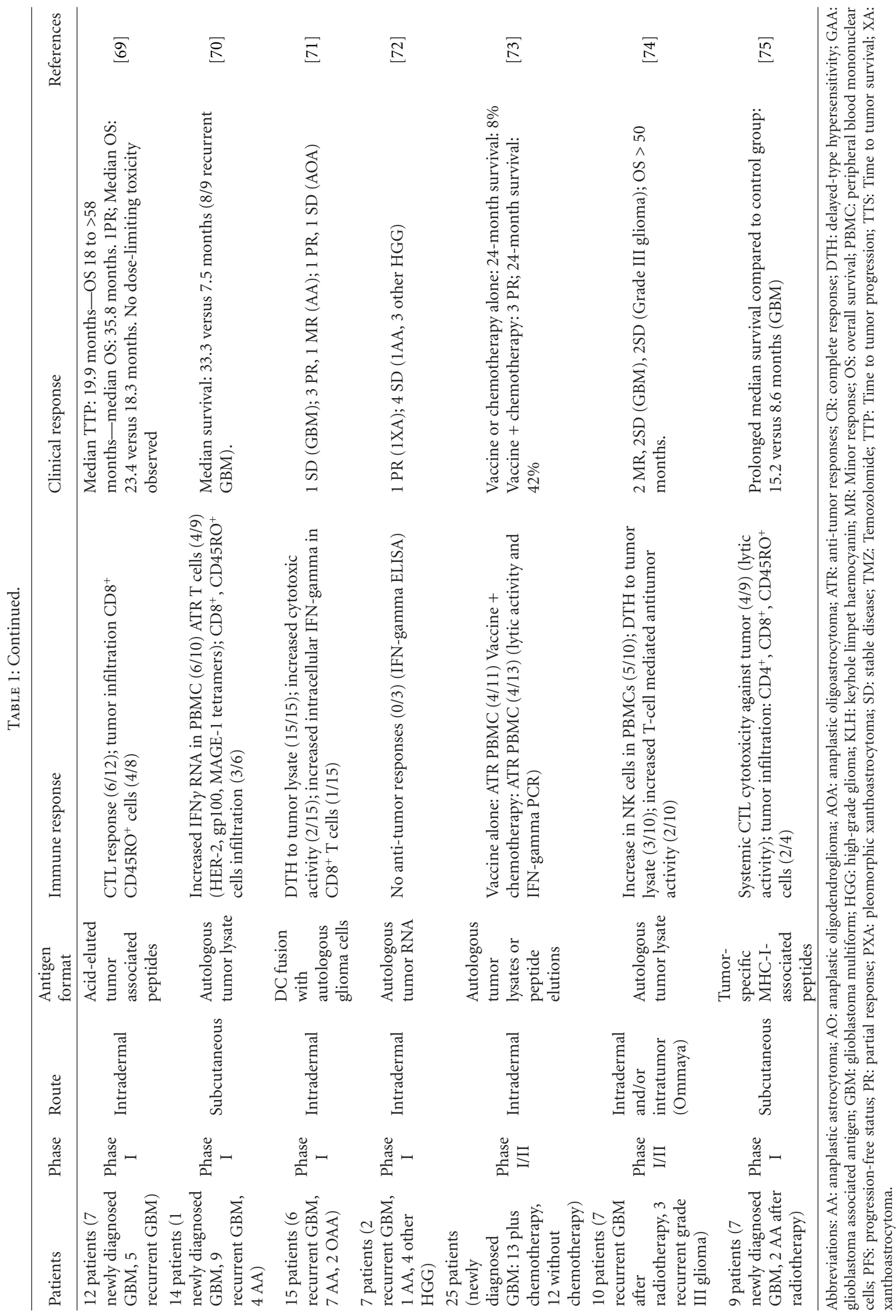


64], TLR ligand: poly ICLC $[61,62]$, IFN-gamma and TNFalpha in combination with IL-4-secreting fibroblasts [78]. In several trials, DCs were matured using cocktails with IL1beta, TNF-alpha, PGE2, or IFN-gamma [7, 63, 64, 74]. The number of DCs injected ranged from $1 \times 10^{6}$ to $1 \times$ $10^{10}$. The frequency of the injections was highly variable. One phase I study focused on the dose of DCs, which did not result in any dose-limiting toxicity [69]. The sources of antigen were quite different: autologous tumor lysates, apoptotic glioma cells peptides eluded from ATCs, synthetic peptides, defined peptides, mRNA derived from ATCs, and irradiated single-cell suspension of ATCs. For vaccinations using ATCs, the ATCs were fused [71] or incubated with DC. Defined peptides were derived from EGFRvIII, the particular target as its frequent expression in GBM $[65,79]$. Vaccines were injected intradermally, intranodally, or subcutaneously. Moreover, in one phase I/II trial, some patients even received intratumoral injections [74].

From all of these clinical studies, only one patient had a large residual tumor and a perilesional edema suffered grade IV neurotoxicity (stupor) [68]. A peripheral immune response such as DTH (delayed-type hypersensitivity) lymphocyte infiltrations, particularly $\mathrm{CD}^{+}$cells, can be observed in more than half of patients. Activated CD8 ${ }^{+}$CTLs efficiently recognize and destroy tumor cells, which expose peptides derived from tumor-associated antigens (TAAs) in human leukocyte antigen (HLA) class I molecules [80]. $\mathrm{CD}^{+} \mathrm{T}$ cells recognizing peptides in the complex of HLA class II molecules also play an important role in antitumor immunity [81]. CD4 ${ }^{+} \mathrm{T}$ cells improve the capacity of DCs to induce CTLs by the interaction between CD40 on DCs and CD40 ligand on activated $\mathrm{CD}^{+}{ }^{+} \mathrm{T}$ cells. In addition, $\mathrm{CD}^{+} \mathrm{T}$ cells help to maintain and expand CTLs by secreting cytokines such as IL-2. Beside their extraordinary capacity to elicit T-cell responses, DCs efficiently improve the immunomodulatory and cytotoxic potential of natural killer cells, which are also involved in the elimination of tumor $[82,83]$. Furthermore, DCs can also directly mediate tumordirected cytotoxicity [84].

Almost fifteen studies have reported on a survival benefit of patients receiving immunotherapies when compared with historical cohorts [61-70, 73-75]. Liau et al. [69] vaccinated four patients showing an increase of intratumoral infiltration by lymphocytes after vaccination at a time when the tumor was minimal. T-cell infiltration correlated with a decrease in intratumoral TGF-beta and was associated with a better survival. Patients without T-cell infiltration showed a reverse effect. Combined intravenous and intracranial administration of ATCs gave a superior response when compared to intravenous injection only [68]. Wheeler et al. reported on the large cohort of 34 GBM patients demonstrating that responders had an increase of IFN-gamma after vaccination when compared with the IFN-gamma level before vaccination using in vitro PBMC stimulation. Moreover, responders to vaccination showed a better response to chemotherapy which was delivered in a second phase [67]. Recent phase I and phase I/II studies with 10 newly diagnosed GBM and 13 recurrent GBM, vaccinated intranodally with autologous tumor lysate pulsed on DCs after radiation and chemotherapy or synthetic peptides for GAA epitopes showed a good immune response and a prolonged survival $[61,85]$.

As a consequence, active immunotherapy appears to have a beneficial effect in some patients, particularly in those with a limited tumor, without causing major toxicity. Both clinical trials using ATCs and DC demonstrate induced immune responses (DTH reaction, tumor infiltration, and/or antitumor responses of PBMC) and some clinical responses. The important take-home message for DC vaccination is that no dose-related toxicity has been demonstrated [69]. In addition, it seems better to use mature DC compared to immature DC. Due to the large variability of protocols tested, the source of ATCs, and the type and the cell number of DC injected, the type of adjuvants, no proven approach can be presented so far.

Various antigen sources can be used for DC active immunotherapy. Peptides are very popular; however, loading DCs with peptides requires a large culture of autologous tumor cells, which is a complex process. To break this limitation, some trials load DCs with tumor lysate instead of eluted peptides. Yu et al. [75] found T-cell-mediated cytotoxicity in $60 \%$ of the patients after immunization with tumor lysateloaded DCs, a success rate higher than the $40 \%$ value seen with eluted peptides by the same team [70]. In another phase I/II trial, 24 patients with recurrent malignant gliomas were treated with intradermal or intratumoral (Ommaya reservoir) injections of DCs loaded with tumor lysate. Some patients also received intratumoral injections. One PR and three MR were observed [68]. A novel development in cancer vaccines consists of fusing tumor cells with DCs, a strategy that has been associated with clinical responses in patients with glioma [71].

\subsubsection{Antigens for GBM Immunotherapy}

(1) Glioblastoma-Associated Antigens (GAAs). Recently, many efforts have been made to identify tumor-associated proteins as targets of tumor-reactive $\mathrm{T}$ cells and to define peptide motifs within these proteins constituting T-cell epitopes. In this paper, we focus on glioblastoma-associated antigens (GAAs), which have already been used for DCbased vaccination trials enrolling GBM patients. GAAs such as EGFRvIII, EphA2, GP100, HER2, MAGE-1, IL$13 \mathrm{R} \alpha 2$, SOX11, and TRP2 [86-89], which were frequently overexpressed in GBMs, were able to initiate immune responses. Other antigens associated with GBM have been described including survivin, WT1, SOX2, AIM2, SART1, SART2, and SART3 [90]. T cells directed against IL-13R $\alpha 2$ and EphA2 have been demonstrated in the PBMCs of a long surviving patient with anaplastic astrocytoma, showing that a spontaneous immune reaction can be observed in highgrade glioma [91]. Many glioblastoma-associated antigens were identified within either glioblastoma cell lines or GBM cells, such as ART and SART [92]. "Cancer-testis antigens" are differentially expressed in testis and tumors including MAGE-1, GAGE-1, and NY-ESO-1. These antigens were found in terminally differentiated melanocytes and also in 


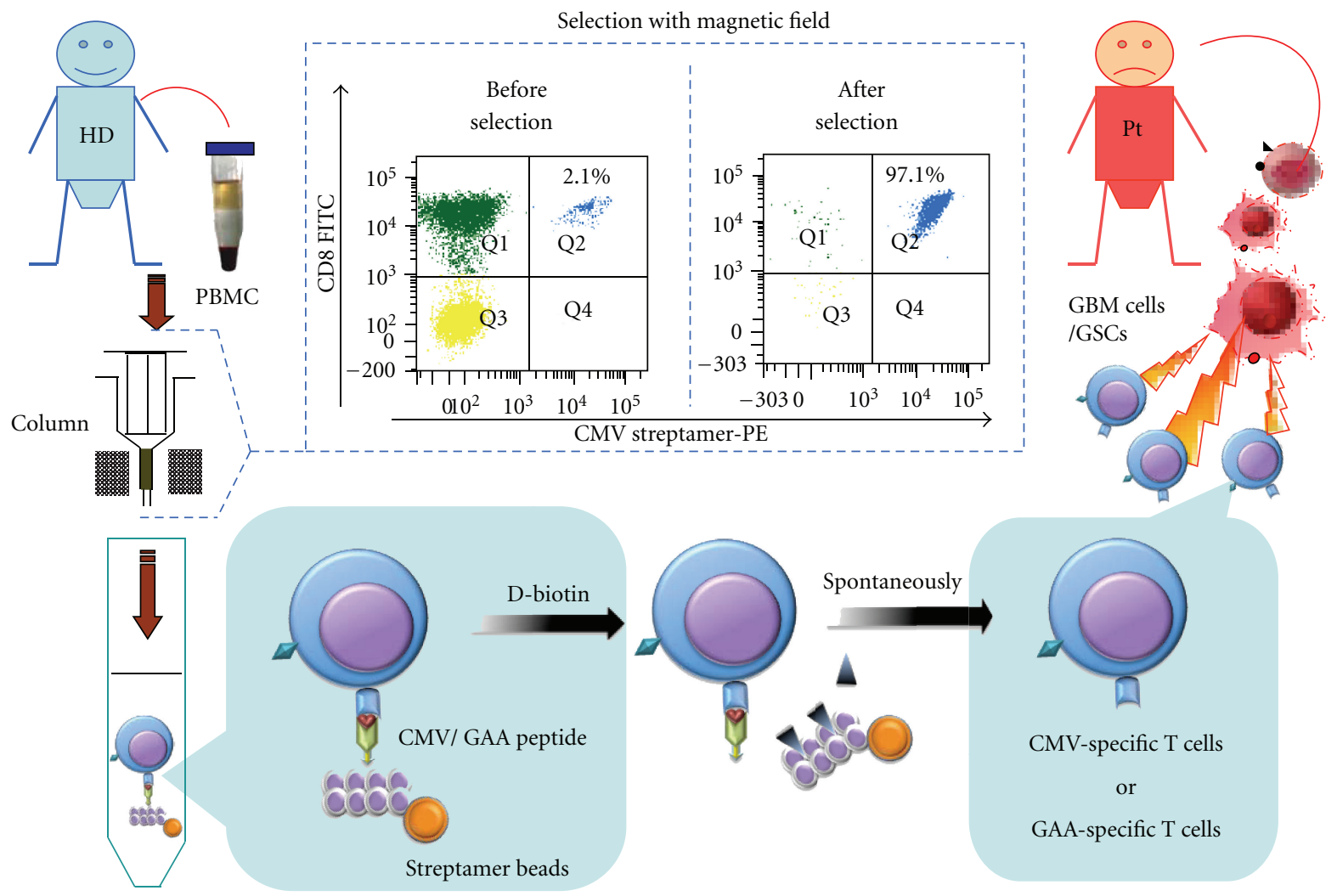

FIGURE 2: Adoptive immunotherapy for GBM patients with CMV or GAA peptides. CMV and GAAs are highly expressed in GBM, but neither in healthy brain tissue, nor in nonmalignant brain tumors. Therefore, GAAs constitute good targets for immunotherapy of GBM patients. The streptamer technology offers the advantage of selecting CMV- or GAA-specific CD8 ${ }^{+}$CTLs at the good manufacturing practice (GMP) level in vitro. PBMCs from healthy donors are collected and isolated by streptamer beads. Noninduced antigen-specific T cells are purified and accumulated through a magnetic field and released by D-biotin from the streptamer complex. Subsequently, these cells are administered to the GBM patient. CMV/GAA-specific cytotoxic T cells can recognize the target antigens which are presented on the surface of GBM cells or GSCs. Cytotoxicity is exerted directly through the Fas or perforin pathway and/or indirectly by the release of cytokines. CMV: cytomegalovirus; GAA: glioblastoma associated antigen; GBM: glioblastoma multiforme; GSCs: glioblastoma stem cells; HD: healthy donor; PBMC: peripheral blood mononuclear cells; Pt: patient.

GBMs [93-95]. TRP-1 and TRP-2 were not found in the testis but were detected in normal cells like melanocytes as well transformed tissues like melanomas and glioblastomas [89]. Since melanoma and glioblastoma cells share a common embryonic neuroectoderm precursor, it is not that surprising that these two cancer types share many common antigens. Here, we summarized the key GAAs in Table 2 [79, 89-123].

(2) Viral Antigens. Viral antigens act as good targets for antiinfectious immunity. Moreover, many viruses such as HTLV1, hepatitis B and C virus, and EBV/JCV play a critical role in several human cancers as well. Cytomegalovirus (CMV, a common, typically harmless herpes virus) is frequently detected within chronically immunosuppressed patients. It is thought that up to $90 \%$ of the population might be chronically infected with CMV. However, our immune system keeps them under tight control. GBM patients are considered to be immunosuppressed through many mechanisms [124]. So the CMV can revive whenever the immune system is impaired. In 2002, Dr. Cobbs et al. [125] linked CMV with human GBM. They analyzed GBM samples from 22 patients and found that all of them harbored CMV. $80 \%$ people have this virus, which remains in the body for remaining lifespan. Whether CMV directly causes GBM is still a hot topic and is also controversial. The possibility that CMV attaches itself to GBM via the platelet-derived growth factor alpha allows some interesting therapies to be explored. One CMV antigen, pp65, induced a HLA-A2 restricted immune response in a GBM patient [126]. Freshly isolated GBM samples seem to highly express this CMVpp65 antigen, but cell lines lose this ability [127]. If a high number of GBM cells harbor CMV or express CMV antigen in vivo, this might open the door towards developing CMV peptides to vaccinate against the virus and the tumor at the same time (Figure 2). Currently, after learning about Dr. Cobbs's work, Dr. Mitchell and his colleagues first confirmed the basic findings. They discovered CMV in the tumors of more than $90 \%$ of those patients with GBM, but not in healthy brain tissue nor in nonmalignant brain tumors [127]. Then used DC-based vaccines-targeting CMV antigens to treat 21 patients who had been diagnosed with GBM. Allogeneic CMV-specific CTLs have been used for treating glioma patients by the research group from 


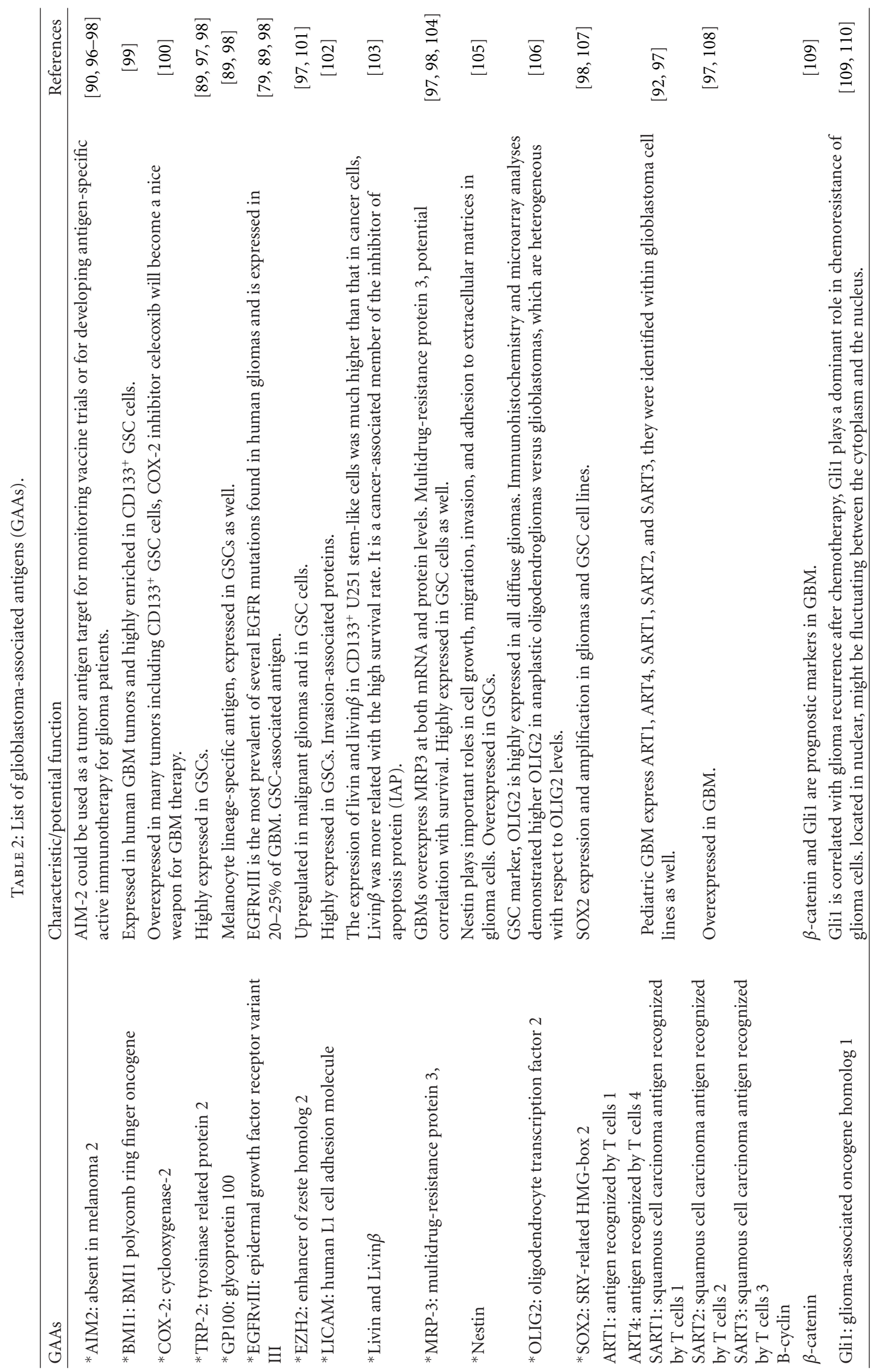




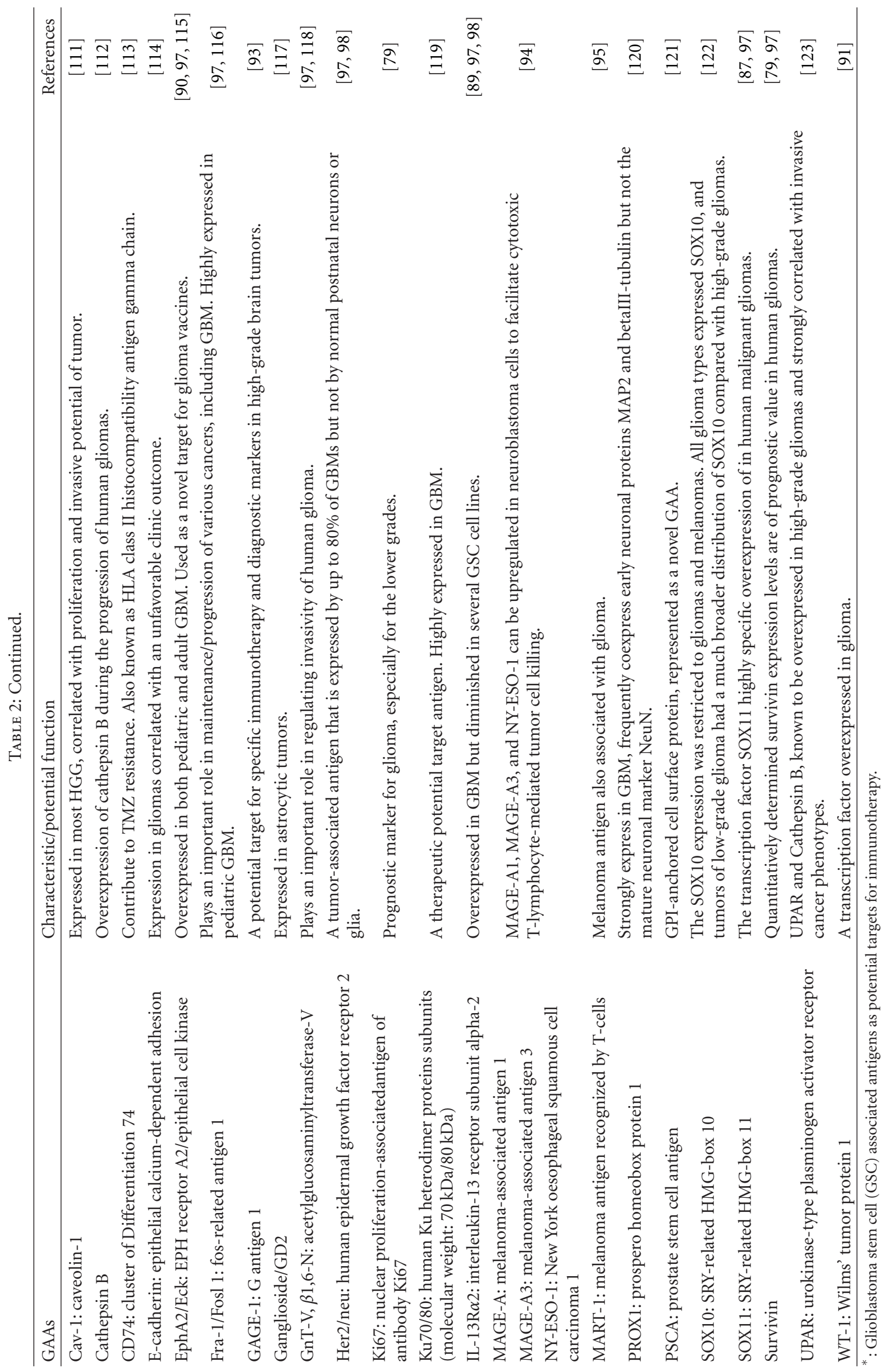


Pennsylvania State University [128, 129]. Yao et al. [130] and Schmitt et al. [131] showed that the streptamer technology offered the advantage of selecting CMVpp65-specific CD8 ${ }^{+}$ CTLs at the good manufacturing practice level in vitro. This strategy might then be used for adoptive immunotherapy for GBM patients in the future (Figure 2). CMV-specific T cells might constitute a key of the useful immunological tool to attack GBM.

\subsection{Role of Regulatory T Cells and Th17 Cells in Immunother-} apy. $\mathrm{CD}^{+}$regulatory $\mathrm{T}$ cells (Tregs) play a key role in maintaining immune homeostasis. They have been well characterized as a distinct subpopulation of $\mathrm{T}$ cells due to the identification of the forkhead box transcription factor 3 (Foxp3) as an essential transcription factor in Tregs [132]. The investigation of Treg in brain tumor has blossomed in the last five years. The $\mathrm{CD} 4^{+}, \mathrm{CD} 25^{+}\left(\mathrm{IL}-2 \mathrm{R} \alpha^{+}\right)$, and Foxp $3^{+}$Tregs were most frequently found in GBM but very rarely in lowgrade astrocytomas and were not present in normal brain tissue. Treg infiltration differed significantly in the brain tumor according to lineage, pathology, and grade. Under the microenvironmental conditions in the GBM patients, Tregs work in several ways to inhibit the effect of T-cell response and act as immune suppressors [133-135]. This might cause the failure of elimination of GBM with glioblastoma infiltrating lymphocytes in clinical trials. Options to eliminate Treg function will likely improve clinical results in future trials. Daclizumab is an approved antibody against IL-2R, which can be used for Treg elimination. Tregs share a common early-stage pathway with another type of $\mathrm{CD}^{+} \mathrm{IL}^{-17 \mathrm{~A}^{+}} \mathrm{T}$ helper cell, called Th17 cells [136, 137]. Naive T cells upon exposure to antigen and TGF-beta can generate mouse Th17 cells, but not human Th17 cells. For generating Th17 cells, the presence of IL- 6 is required. Both cytokines are produced by GBMs. In a melanoma-bearing mouse model, Th17 cells could be used to clear large-established tumor cells [138]. To date, the presence of Th17 cells was confirmed in both human and mouse glioma as well [139], but their beneficial or inhibitory actions have not been fully understood.

3.4. Myeloid-Derived Suppressor Cells (MDSCs). GBM patients are immunosuppressed and have more circulating myeloid-derived suppressor cells (MDSCs) when compared to normal donors. Interestingly, MDSCs might be generated from glioma-conditioned monocytes in vitro [140]. As Raychaudhuri et al. reported in 2011, GBM patients have increased MDSCs counts $\left(\mathrm{CD} 33^{+} \mathrm{HLA}^{-D R^{-}}\right)$in their peripheral blood. The accumulation of MDSCs in patients with GBM promotes T-cell immune suppression. Increased plasma levels of arginase and granulocyte colony-stimulating factor may relate to MDSC suppressor function and MDSC expansion, respectively. Removing MDSCs from the PBMCs with anti-CD33/CD15-coated beads significantly restored Tcell function [141].

3.5. GBM Stem Cells (GSCs). Relapse of GBM is attributed to the persistence of hibernating tumor stem cells [142]. The existence of GBM stem cells is also correlated with multidrug and radiation resistance in GBM $[143,144]$. In the past few years, one of the neural progenitor cells marker, CD133, was described as a reasonable marker for GSCs as well [145]. However, some GSCs were also reported to be CD133 negative [146]. So the actual concept of GSCs still needs to be defined.

A safe and effective immune response against rodent gliomas can be elicited by using GSC cell lines as a vaccine in rodent models [147]. Glioblastoma-associated antigens such as AIM2, BMI1, COX-2, TRP2, GP100, EGFRv III, EZH2, LICAM, Livin/Livin $\beta$, MRP3, NESTIN, OLIG2, and SOX2 are present on these human GSCs. In contrast, IL-13R $\alpha 2$ and HER2 seem to be decreased in these GSCs [98]. Two studies suggest that GSCs can differentiate into glioma endothelial cells [148, 149]. GSCs might be considered as sources of antigens for DC vaccination against human GBM, with the aim of achieving GSC-targeting and better antitumor immunity (Figure 1).

\section{Future Perspective}

Recently, several studies have reported that the combination of chemotherapy and immunotherapy may be more effective than single-modality treatment alone $[150,151]$. Kim et al. demonstrated that in a GL26 glioma model, a combination of low-dose TMZ chemotherapy and transactivation of transcription (TAT)-based DC immunotherapy may be a novel strategy for safe and effective treatment of malignant gliomas. TAT contains a protein transduction domain and could be used as an efficient carrier [152].

Our recent work also showed that TMZ might not be deleterious but rather beneficial to immunomodulatory therapy of GBM patients [153].

Future developments in DC vaccination for GBM might include transfection/nucleofection of DCs with RNA encoding for GAA, cytokines, or TLRs.

\section{Acknowledgments}

This paper was supported by the German José Carreras Leukemia Foundation (DJCLS, Project no. R09/14 and R10/ 03). The authors would like to thank Dr. Benjamin Pierce for making suggestions on the paper from the perspective of a native speaker.

\section{References}

[1] A. Fleury, F. Menegoz, P. Grosclaude et al., "Descriptive epidemiology of cerebral gliomas in France," Cancer, vol. 79, no. 6, pp. 1195-1202, 1997.

[2] R. O. Mirimanoff, T. Gorlia, W. Mason et al., "Radiotherapy and temozolomide for newly diagnosed glioblastoma: recursive partitioning analysis of the EORTC 26981/22981-NCIC CE3 phase III randomized trial," Journal of Clinical Oncology, vol. 24, no. 16, pp. 2563-2569, 2006.

[3] W. Stummer, H. J. Reulen, T. Meinel et al., "Extent of resection and survival in glioblastoma multiforme: identification of and adjustment for bias," Neurosurgery, vol. 62, no. 3, pp. 564-576, 2008. 
[4] W. Stummer, U. Pichlmeier, T. Meinel, O. D. Wiestler, F. Zanella, and H. J. Reulen, "Fluorescence-guided surgery with 5-aminolevulinic acid for resection of malignant glioma: a randomised controlled multicentre phase III trial," The Lancet Oncology, vol. 7, no. 5, pp. 392-401, 2006.

[5] F. Stockhammer, M. Misch, P. Horn, A. Koch, N. Fonyuy, and M. Plotkin, "Association of F18-fluoro-ethyl-tyrosin uptake and 5-aminolevulinic acid-induced fluorescence in gliomas," Acta Neurochirurgica, vol. 151, no. 11, pp. 1377-1383, 2009.

[6] M. Westphal, Z. Ram, V. Riddle, D. Hilt, and E. Bortey, "Gliadel wafer in initial surgery for malignant glioma: longterm follow-up of a multicenter controlled trial," Acta Neurochirurgica, vol. 148, no. 3, pp. 269-275, 2006.

[7] P. Menei, P. Metellus, E. Parot-Schinkel et al., "Biodegradable carmustine wafers (Gliadel) alone or in combination with chemoradiotherapy: the French experience," Annals of Surgical Oncology, vol. 17, no. 7, pp. 1740-1746, 2010.

[8] F. W. Kreth, P. C. Warnke, R. Scheremet, and C. B. Ostertag, "Surgical resection and radiation therapy versus biopsy and radiation therapy in the treatment of glioblastoma multiforme," Journal of Neurosurgery, vol. 78, no. 5, pp. 762-766, 1993.

[9] F. W. Kreth, A. Muacevic, R. Medele, K. Bise, T. Meyer, and H. J. Reulen, "The risk of haemorrhage after image guided stereotactic biopsy of intra-axial brain tumours-a prospective study," Acta Neurochirurgica, vol. 143, no. 6, pp. 539-546, 2001.

[10] E. M. Grasbon-Frodl, F. W. Kreth, M. Ruiter et al., "Intratumoral homogeneity of MGMT promoter hypermethylation as demonstrated in serial stereotactic specimens from anaplastic astrocytomas and glioblastomas," International Journal of Cancer, vol. 121, no. 11, pp. 2458-2464, 2007.

[11] R. Stupp, W. P. Mason, M. J. Van Den Bent et al., "Radiotherapy plus concomitant and adjuvant temozolomide for glioblastoma," The New England Journal of Medicine, vol. 352, no. 10, pp. 987-996, 2005.

[12] R. Stupp, M. E. Hegi, W. P. Mason et al., "Effects of radiotherapy with concomitant and adjuvant temozolomide versus radiotherapy alone on survival in glioblastoma in a randomised phase III study: 5-year analysis of the EORTCNCIC trial," The Lancet Oncology, vol. 10, no. 5, pp. 459-466, 2009.

[13] M. E. Hegi, A. C. Diserens, T. Gorlia et al., "MGMT gene silencing and benefit from temozolomide in glioblastoma," The New England Journal of Medicine, vol. 352, no. 10, pp. 997-1003, 2005.

[14] P. Hau, D. Koch, T. Hundsberger et al., "Safety and feasibility of long-term temozolomide treatment in patients with highgrade glioma," Neurology, vol. 68, no. 9, pp. 688-690, 2007.

[15] G. M. V. Barbagallo, M. D. Jenkinson, and A. R. Brodbelt, "'Recurrent' glioblastoma multiforme, when should we reoperate?" British Journal of Neurosurgery, vol. 22, no. 3, pp. 452 455,2008

[16] E. S. Mandl, C. M. F. Dirven, D. R. Buis, T. J. Postma, and W. P. Vandertop, "Repeated surgery for glioblastoma multiforme: only in combination with other salvage therapy," Surgical Neurology, vol. 69, no. 5, pp. 506-509, 2008.

[17] S. E. Combs, M. Bischof, T. Welzel et al., "Radiochemotherapy with temozolomide as re-irradiation using high precision fractionated stereotactic radiotherapy (FSRT) in patients with recurrent gliomas," Journal of Neuro-Oncology, vol. 89, no. 2, pp. 205-210, 2008.

[18] A. T. Villavicencio, S. Burneikiene, P. Romanelli et al., "Survival following stereotactic radiosurgery for newly diag- nosed and recurrent glioblastoma multiforme: a multicenter experience," Neurosurgical Review, vol. 32, no. 4, pp. 417424, 2009.

[19] T. Cloughesy, "FDA accelerated approval benefits glioblastoma," The Lancet Oncology, vol. 11, no. 12, p. 1120, 2010.

[20] J. J. Vredenburgh, A. Desjardins, J. E. Herndon et al., "Phase II trial of bevacizumab and irinotecan in recurrent malignant glioma," Clinical Cancer Research, vol. 13, no. 4, pp. 12531259, 2007.

[21] J. J. Vredenburgh, A. Desjardins, J. E. Herndon et al., "Bevacizumab plus irinotecan in recurrent glioblastoma multiforme," Journal of Clinical Oncology, vol. 25, no. 30, pp. 47224729, 2007.

[22] H. S. Friedman, M. D. Prados, P. Y. Wen et al., "Bevacizumab alone and in combination with irinotecan in recurrent glioblastoma," Journal of Clinical Oncology, vol. 27, no. 28, pp. 4733-4740, 2009.

[23] A. A. Brandes, A. Tosoni, G. Cavallo et al., "Temozolomide 3 weeks on and 1 week off as first-line therapy for recurrent glioblastoma: phase II study from gruppo italiano cooperativo di neuro-oncologia (GICNO)," British Journal of Cancer, vol. 95, no. 9, pp. 1155-1160, 2006.

[24] A. Wick, J. Felsberg, J. P. Steinbach et al., "Efficacy and tolerability of temozolomide in an alternating weekly regimen in patients with recurrent glioma," Journal of Clinical Oncology, vol. 25, no. 22, pp. 3357-3361, 2007.

[25] J. R. Perry, P. Rizek, R. Cashman, M. Morrison, and T. Morrison, "Temozolomide rechallenge in recurrent malignant glioma by using a continuous temozolomide schedule: the "rescue" approach," Cancer, vol. 113, no. 8, pp. 2152-2157, 2008.

[26] F. Stockhammer, M. Misch, A. Koch et al., "Continuous lowdose temozolomide and celecoxib in recurrent glioblastoma," Journal of Neuro-Oncology, vol. 100, no. 3, pp. 407-415, 2010.

[27] P. Hau, U. Baumgart, K. Pfeifer et al., "Salvage therapy in patients with glioblastoma: is there any benefit?" Cancer, vol. 98, no. 12, pp. 2678-2686, 2003.

[28] S. Hong and L. Van Kaer, "Immune privilege: keeping an eye on natural killer T cells," The Journal of Experimental Medicine, vol. 190, no. 9, pp. 1197-1200, 1999.

[29] C. W. Kanaly, D. Ding, A. B. Heimberger, and J. H. Sampson, "Clinical applications of a peptide-based vaccine for glioblastoma," Neurosurgery Clinics of North America, vol. 21, no. 1, pp. 95-109, 2010.

[30] E. Thara, T. B. Dorff, J. K. Pinski, and D. I. Quinn, "Vaccine therapy with sipuleucel-T (Provenge) for prostate cancer," Maturitas, vol. 69, no. 4, pp. 296-303, 2011.

[31] S. K. Jacobs, D. J. Wilson, P. L. Kornblith, and E. A. Grimm, "Interleukin-2 or autologous lymphokine-activated killer cell treatment of malignant glioma: phase I trial," Cancer Research, vol. 46, no. 4, pp. 2101-2104, 1986.

[32] R. E. Merchant, A. J. Grant, L. H. Merchant, and H. F. Young, "Adoptive immunotherapy for recurrent glioblastoma multiforme using lymphokine activated killer cells and recombinant interleukin-2," Cancer, vol. 62, no. 4, pp. 665671, 1988.

[33] D. Barba, S. C. Saris, C. Holder, S. A. Rosenberg, and E. H. Oldfield, "Intratumoral LAK cell and interleukin-2 therapy of human gliomas," Journal of Neurosurgery, vol. 70, no. 2, pp. 175-182, 1989.

[34] K. O. Lillehei, D. H. Mitchell, S. D. Johnson, E. L. McCleary, and C. A. Kruse, "Long-term follow-up of patients with recurrent malignant gliomas treated with adjuvant adoptive 
immunotherapy," Neurosurgery, vol. 28, no. 1, pp. 16-23, 1991.

[35] E. W. B. Jeffes III, Y. B. Beamer, S. Jacques et al., "Therapy of recurrent high grade gliomas with surgery, and autologous mitogen activated IL-2 stimulated killer (MAK) lymphocytes: I. Enhancement of MAK lytic activity and cytokine production by PHA and clinical use of PHA," Journal of Neuro-Oncology, vol. 15, no. 2, pp. 141-155, 1993.

[36] A. Blancher, F. Roubinet, A. S. Grancher et al., "Local immunotherapy of recurrent glioblastoma multiforme by intracerebral perfusion of interleukin-2 and LAK cells," European Cytokine Network, vol. 4, no. 5, pp. 331-341, 1993.

[37] A. Boiardi, A. Silvani, P. Adelchi Ruffini et al., "Loco-regional immunotherapy with recombinant interleukin-2 and adherent lymphokine-activated killer cells (A-LAK) in recurrent glioblastoma patients," Cancer Immunology Immunotherapy, vol. 39, no. 3, pp. 193-197, 1994.

[38] R. L. Hayes, M. Koslow, E. M. Hiesiger et al., "Improved long term survival after intracavitary interleukin-2 and lymphokine-activated killer cells for adults with recurrent malignant glioma," Cancer, vol. 76, no. 5, pp. 840-852, 1995.

[39] S. K. Sankhla, J. S. Nadkarni, and S. N. Bhagwati, "Adoptive immimotherapy using lymphokine-activated killer (LAK) cells and interleukin-2 for recurrentmalignant primary brain tumors," Journal of Neuro-Oncology, vol. 27, no. 2, pp. 133140, 1995.

[40] R. L. Hayes, E. Arbit, M. Odaimi et al., "Adoptive cellular immunotherapy for the treatment of malignant gliomas," Critical Reviews in Oncology/Hematology, vol. 39, no. 1-2, pp. 31-42, 2001.

[41] R. O. Dillman, C. M. Duma, P. M. Schiltz et al., "Intracavitary placement of autologous lymphokine-activated killer (LAK) cells after resection of recurrent glioblastoma," Journal of Immunotherapy, vol. 27, no. 5, pp. 398-404, 2004.

[42] R. O. Dillman, C. M. Duma, R. A. Ellis et al., "Intralesional lymphokine-activated killer cells as adjuvant therapy for primary glioblastoma," Journal of Immunotherapy, vol. 32, no. 9, pp. 914-919, 2009.

[43] F. P. Holladay, "Autologous tumor cell vaccination combined with adoptive cellular immunotherapy in patients with Grade III/IV astrocytoma," Journal of Neuro-Oncology, vol. 27, no. 2, pp. 179-189, 1996.

[44] G. E. Plautz, G. H. Barnett, D. W. Miller et al., "Systemic T cell adoptive immunotherapy of malignant gliomas," Journal of Neurosurgery, vol. 89, no. 1, pp. 42-51, 1998.

[45] G. E. Plautz, D. W. Miller, G. H. Barnett et al., "T cell adoptive immunotherapy of newly diagnosed gliomas," Clinical Cancer Research, vol. 6, no. 6, pp. 2209-2218, 2000.

[46] G. W. Wood, F. P. Holladay, T. Turner, Y. Y. Wang, and M. Chiga, "A pilot study of autologous cancer cell vaccination and cellular immunotherapy using anti-CD3 stimulated lymphocytes in patients with recurrent grade III/IV astrocytoma," Journal of Neuro-Oncology, vol. 48, no. 2, pp. 113-120, 2000.

[47] A. E. Sloan, R. Dansey, L. Zamorano et al., "Adoptive immunotherapy in patients with recurrent malignant glioma: preliminary results of using autologous whole-tumor vaccine plus granulocyte-macrophage colony-stimulating factor and adoptive transfer of anti-CD3-activated lymphocytes," Neurosurgical Focus, vol. 9, no. 6, p. e9, 2000.

[48] C. A. Kruse, L. Cepeda, B. Owens, S. D. Johnson, J. Stears, and K. O. Lillehei, "Treatment of recurrent glioma with intracavitary alloreactive cytotoxic $\mathrm{T}$ lymphocytes and inter- leukin-2," Cancer Immunology Immunotherapy, vol. 45, no. 2, pp. 77-87, 1997.

[49] K. B. Quattrocchi, C. H. Miller, S. Cush et al., "Pilot study of local autologous tumor infiltrating lymphocytes for the treatment of recurrent malignant gliomas," Journal of NeuroOncology, vol. 45, no. 2, pp. 141-157, 1999.

[50] N. Kronik, Y. Kogan, V. Vainstein, and Z. Agur, "Improving alloreactive CTL immunotherapy for malignant gliomas using a simulation model of their interactive dynamics," Cancer Immunology, Immunotherapy, vol. 57, no. 3, pp. 425-439, 2008.

[51] R. E. Sobol, H. Fakhrai, D. Shawler et al., "Interleukin-2 gene therapy in a patient with glioblastoma," Gene Therapy, vol. 2, no. 2, pp. 164-167, 1995.

[52] T. Schneider, R. Gerhards, E. Kirches, and R. Firsching, "Preliminary results of active specific immunization with modified tumor cell vaccine in glioblastoma multiforme," Journal of Neuro-Oncology, vol. 53, no. 1, pp. 39-46, 2001.

[53] D. W. Andrews, M. Resnicoff, A. E. Flanders et al., "Results of a pilot study involving the use of an antisense oligodeoxynucleotide directed against the insulin-like growth factor type I receptor in malignant astrocytomas," Journal of Clinical Oncology, vol. 19, no. 8, pp. 2189-2200, 2001.

[54] H. Okada, F. S. Lieberman, H. D. Edington et al., "Autologous glioma cell vaccine admixed with interleukin-4 gene transfected fibroblasts in the treatment of recurrent glioblastoma: preliminary observations in a patient with a favorable response to therapy," Journal of Neuro-Oncology, vol. 64, no. 1-2, pp. 13-20, 2003.

[55] H. H. Steiner, M. M. Bonsanto, P. Beckhove et al., "Antitumor vaccination of patients with glioblastoma multiforme: a pilot study to assess feasibility, safety, and clinical benefits," Journal of Clinical Oncology, vol. 22, no. 21, pp. 4272-4281, 2004.

[56] I. F. Parney, L. J. Chang, M. A. Farr-Jones, C. Hao, M. Smylie, and K. C. Petruk, "Technical hurdles in a pilot clinical trial of combined B7-2 and GM-CSF immunogene therapy for glioblastomas and melanomas," Journal of Neuro-Oncology, vol. 78, no. 1, pp. 71-80, 2006.

[57] E. Ishikawa, K. Tsuboi, T. Yamamoto et al., "Clinical trial of autologous formalin-fixed tumor vaccine for glioblastoma multiforme patients," Cancer Science, vol. 98, no. 8, pp. 12261233, 2007.

[58] A. Clavreul, N. Piard, J. Y. Tanguy et al., "Autologous tumor cell vaccination plus infusion of GM-CSF by a programmable pump in the treatment of recurrent malignant gliomas," Journal of Clinical Neuroscience, vol. 17, no. 7, pp. 842-848, 2010.

[59] J. Banchereau, F. Briere, C. Caux et al., "Immunobiology of dendritic cells," Annual Review of Immunology, vol. 18, pp. 767-811, 2000.

[60] R. M. Steinman and J. Banchereau, "Taking dendritic cells into medicine," Nature, vol. 449, no. 7161, pp. 419-426, 2007.

[61] H. Okada, P. Kalinski, R. Ueda et al., "Induction of $\mathrm{CD}^{+}$Tcell responses against novel glioma-associated antigen peptides and clinical activity by vaccinations with $\alpha$-type 1 polarized dendritic cells and polyinosinic-polycytidylic acid stabilized by lysine and carboxymethylcellulose in patients with recurrent malignant glioma," Journal of Clinical Oncology, vol. 29, no. 3, pp. 330-336, 2011.

[62] R. M. Prins, H. Soto, V. Konkankit et al., "Gene expression profile correlates with T-cell infiltration and relative survival in glioblastoma patients vaccinated with dendritic cell immunotherapy," Clinical Cancer Research, vol. 17, no. 6, pp. 1603-1615, 2011. 
[63] H. Ardon, S. Van Gool, I. S. Lopes et al., "Integration of autologous dendritic cell-based immunotherapy in the primary treatment for patients with newly diagnosed glioblastoma multiforme: a pilot study," Journal of Neuro-Oncology, vol. 99, no. 2, pp. 261-272, 2010.

[64] H. Ardon, S. De Vleeschouwer, F. Van Calenbergh et al., "Adjuvant dendritic cell-based tumour vaccination for children with malignant brain tumours," Pediatric Blood and Cancer, vol. 54, no. 4, pp. 519-525, 2010.

[65] J. H. Sampson, G. E. Archer, D. A. Mitchell et al., "An epidermal growth factor receptor variant III-targeted vaccine is safe and immunogenic in patients with glioblastoma multiforme," Molecular Cancer Therapeutics, vol. 8, no. 10, pp. 2773-2779, 2009.

[66] S. De Vleeschouwer, S. Fieuws, S. Rutkowski et al., "Postoperative adjuvant dendritic cell-based immunotherapy in patients with relapsed glioblastoma multiforme," Clinical Cancer Research, vol. 14, no. 10, pp. 3098-3104, 2008.

[67] C. J. Wheeler, K. L. Black, G. Liu et al., "Vaccination elicits correlated immune and clinical responses in glioblastoma multiforme patients," Cancer Research, vol. 68, no. 14, pp. 5955-5964, 2008.

[68] R. Yamanaka, J. Homma, N. Yajima et al., "Clinical evaluation of dendritic cell vaccination for patients with recurrent glioma: results of a clinical phase I/II trial," Clinical Cancer Research, vol. 11, no. 11, pp. 4160-4167, 2005.

[69] L. M. Liau, R. M. Prins, S. M. Kiertscher et al., "Dendritic cell vaccination in glioblastoma patients induces systemic and intracranial T-cell responses modulated by the local central nervous system tumor microenvironment," Clinical Cancer Research, vol. 11, no. 15, pp. 5515-5525, 2005.

[70] J. S. Yu, G. Liu, H. Ying, W. H. Yong, K. L. Black, and C. J. Wheeler, "Vaccination with tumor lysate-pulsed dendritic cells elicits antigen-specific, cytotoxic T-cells in patients with malignant glioma," Cancer Research, vol. 64, no. 14, pp. 49734979, 2004.

[71] T. Kikuchi, Y. Akasaki, T. Abe et al., "Vaccination of glioma patients with fusions of dendritic and glioma cells and recombinant human interleukin 12," Journal of Immunotherapy, vol. 27, no. 6, pp. 452-459, 2004.

[72] D. A. Caruso, L. M. Orme, A. M. Neale et al., "Results of a phase 1 study utilizing monocyte-derived dendritic cells pulsed with tumor RNA in children and young adults with brain cancer," Neuro-Oncology, vol. 6, no. 3, pp. 236-246, 2004.

[73] C. J. Wheeler, A. Das, G. Liu, J. S. Yu, and K. L. Black, "Clinical responsiveness of glioblastoma multiforme to chemotherapy after vaccination," Clinical Cancer Research, vol. 10, no. 16, pp. 5316-5326, 2004.

[74] R. Yamanaka, T. Abe, N. Yajima et al., "Vaccination of recurrent glioma patients with tumour lysate-pulsed dendritic cells elicits immune responses: results of a clinical phase I/II trial," British Journal of Cancer, vol. 89, no. 7, pp. 1172-1179, 2003.

[75] J. S. Yu, C. J. Wheeler, P. M. Zeltzer et al., "Vaccination of malignant glioma patients with peptide-pulsed dendritic cells elicits systemic cytotoxicity and intracranial T-cell infiltration," Cancer Research, vol. 61, no. 3, pp. 842-847, 2001.

[76] C. J. Wheeler, K. L. Black, G. Liu et al., "Thymic CD8 ${ }^{+}$T cell production strongly influences tumor antigen recognition and age-dependent glioma mortality," The Journal of Immunology, vol. 171, no. 9, pp. 4927-4933, 2003.

[77] S. Tuyaerts, J. L. Aerts, J. Corthals et al., "Current approaches in dendritic cell generation and future implications for can- cer immunotherapy," Cancer Immunology, Immunotherapy, vol. 56, no. 10, pp. 1513-1537, 2007.

[78] H. Okada, F. S. Lieberman, K. A. Walter et al., "Autologous glioma cell vaccine admixed with interleukin-4 gene transfected fibroblasts in the treatment of patients with malignant gliomas," Journal of Translational Medicine, vol. 5, article 67, 2007.

[79] M. Kogiku, I. Ohsawa, K. Matsumoto et al., "Prognosis of glioma patients by combined immunostaining for survivin, Ki-67 and epidermal growth factor receptor," Journal of Clinical Neuroscience, vol. 15, no. 11, pp. 1198-1203, 2008.

[80] S. A. Rosenberg, "Cancer vaccines based on the identification of genes encoding cancer regression antigens," Immunology Today, vol. 18, no. 4, pp. 175-182, 1997.

[81] R. F. Wang, "The role of MHC class II-restricted tumor antigens and $\mathrm{CD}^{+}{ }^{+} \mathrm{T}$ cells in antitumor immunity," Trends in Immunology, vol. 22, no. 5, pp. 269-276, 2001.

[82] N. C. Fernandez, A. Lozier, C. Flament et al., "Dendritic cells directly trigger NK cell functions: cross-talk relevant in innate anti-tumor immune responses in vivo," Nature Medicine, vol. 5, no. 4, pp. 405-411, 1999.

[83] R. Wehner, B. Löbel, M. Bornhäuser et al., "Reciprocal activating interaction between 6-sulfo $\mathrm{LacNAc}^{+}$dendritic cells and NK cell," International Journal of Cancer, vol. 124, no. 2, pp. 358-366, 2009.

[84] M. Schmitz, S. Zhao, Y. Deuse et al., “Tumoricidal potential of native blood dendritic cells: direct tumor cell killing and activation of NK cell-mediated cytotoxicity," The Journal of Immunology, vol. 174, no. 7, pp. 4127-4134, 2005.

[85] C. E. Fadul, J. L. Fisher, T. H. Hampton et al., "Immune response in patients with newly diagnosed glioblastoma multiforme treated with intranodal autologous tumor lysatedendritic cell vaccination after radiation chemotherapy," Journal of Immunotherapy, vol. 34, no. 4, pp. 382-389, 2011.

[86] M. Hatano, J. Eguchi, T. Tatsumi et al., "EphA2 as a gliomaassociated antigen: a novel target for glioma vaccines," Neoplasia, vol. 7, no. 8, pp. 717-722, 2005.

[87] M. Schmitz, R. Wehner, S. Stevanovic et al., "Identification of a naturally processed $\mathrm{T}$ cell epitope derived from the gliomaassociated protein SOX11," Cancer Letters, vol. 245, no. 1-2, pp. 331-336, 2007.

[88] G. Liu, H. Ying, G. Zeng, C. J. Wheeler, K. L. Black, and J. S. $\mathrm{Yu}$, "HER-2, gp100, and MAGE-1 are expressed in human glioblastoma and recognized by cytotoxic T cells," Cancer Research, vol. 64, no. 14, pp. 4980-4986, 2004.

[89] S. Saikali, T. Avril, B. Collet et al., "Expression of nine tumour antigens in a series of human glioblastoma multiforme: interest of EGFRvIII, IL-13R $\alpha 2$, gp100 and TRP-2 for immunotherapy," Journal of Neuro-Oncology, vol. 81, no. 2, pp. 139-148, 2007.

[90] H. Okada, G. Kohanbash, X. Zhu et al., "Immunotherapeutic approaches for glioma," Critical Reviews in Immunology, vol. 29, no. 1, pp. 1-42, 2009.

[91] R. Ueda, K. L. Low, X. Zhu et al., "Spontaneous immune responses against glioma-associated antigens in a long term survivor with malignant glioma," Journal of Translational Medicine, vol. 5, article 68, 2007.

[92] J. G. Zhang, C. A. Kruse, L. Driggers et al., "Tumor antigen precursor protein profiles of adult and pediatric brain tumors identify potential targets for immunotherapy," Journal of Neuro-Oncology, vol. 88, no. 1, pp. 65-76, 2008.

[93] D. L. Scarcella, C. W. Chow, M. F. Gonzales, C. Economou, F. Brasseur, and D. M. Ashley, "Expression of MAGE and GAGE in high-grade brain tumors: a potential target for 
specific immunotherapy and diagnostic markers," Clinical Cancer Research, vol. 5, no. 2, pp. 335-341, 1999.

[94] L. Bao, K. Dunham, and K. Lucas, "MAGE-A1, MAGEA3, and NY-ESO-1 can be upregulated on neuroblastoma cells to facilitate cytotoxic T lymphocyte-mediated tumor cell killing," Cancer Immunology, Immunotherapy, vol. 60, no. 9, pp. 1299-1307, 2011.

[95] G. Z. Jian, J. Eguchi, C. A. Kruse et al., "Antigenic profiling of glioma cells to generate allogeneic vaccines or dendritic cellbased therapeutics," Clinical Cancer Research, vol. 13, no. 2, pp. 566-575, 2007.

[96] G. Liu, J. S. Yu, G. Zeng et al., "AIM-2: a novel tumor antigen is expressed and presented by human glioma cells," Journal of Immunotherapy, vol. 27, no. 3, pp. 220-226, 2004.

[97] L. Driggers, J. G. Zhang, E. W. Newcomb, L. Ge, N. Hoa, and M. R. Jadus, "Immunotherapy of pediatric brain tumor patients should include an immunoprevention strategy: a medical hypothesis paper," Journal of Neuro-Oncology, vol. 97, no. 2, pp. 159-169, 2010.

[98] Q. Xu, G. Liu, X. Yuan et al., “Antigen-specific T-cell response from dendritic cell vaccination using cancer stem-like cellassociated antigens," Stem Cells, vol. 27, no. 8, pp. 1734-1740, 2009.

[99] M. Abdouh, S. Facchino, W. Chatoo, V. Balasingam, J. Ferreira, and G. Bernier, "BMI1 sustains human glioblastoma multiforme stem cell renewal," The Journal of Neuroscience, vol. 29, no. 28, pp. 8884-8896, 2009.

[100] T. Shono, P. J. Tofilon, J. M. Bruner, O. Owolabi, and F. F. Lang, "Cyclooxygenase-2 expression in human gliomas: prognostic significance and molecular correlations," Cancer Research, vol. 61, no. 11, pp. 4375-4381, 2001.

[101] F. Orzan, S. Pellegatta, P. L. Poliani et al., "Enhancer of Zeste 2 (EZH2) is up-regulated in malignant gliomas and in glioma stem-like cells," Neuropathology and Applied Neurobiology, vol. 37, no. 4, pp. 381-394, 2011.

[102] L. Cheng, Q. Wu, O. A. Guryanova et al., "Elevated invasive potential of glioblastoma stem cells," Biochemical and Biophysical Research Communications, vol. 406, no. 4, pp. 643 648, 2011.

[103] F. Jin, L. Zhao, Y. J. Guo et al., "Influence of Etoposide on anti-apoptotic and multidrug resistance-associated protein genes in CD133 positive U251 glioblastoma stem-like cells," Brain Research, vol. 1336, pp. 103-111, 2010.

[104] C. T. Kuan, K. Wakiya, J. E. Herndon et al., "MRP3: a molecular target for human glioblastoma multiforme immunotherapy," BMC Cancer, vol. 10, article 468, 2010.

[105] T. Ishiwata, K. Teduka, T. Yamamoto, K. Kawahara, Y. Matsuda, and Z. Naito, "Neuroepithelial stem cell marker nestin regulates the migration, invasion and growth of human gliomas," Oncology Reports, vol. 26, no. 1, pp. 91-99, 2011.

[106] K. L. Ligon, J. A. Alberta, A. T. Kho et al., "The oligodendroglial lineage marker OLIG2 is universally expressed in diffuse gliomas," Journal of Neuropathology and Experimental Neurology, vol. 63, no. 5, pp. 499-509, 2004.

[107] L. Annovazzi, M. Mellai, V. Caldera, G. Valente, and D. Schiffer, "SOX2 expression and amplification in gliomas and glioma cell lines," Cancer Genomics and Proteomics, vol. 8, no. 3, pp. 139-147, 2011.

[108] S. Kakino, K. Sasaki, A. Kurose, and H. Ito, "Intracellular localization of cyclin B1 during the cell cycle in glioma cells," Cytometry, vol. 24, no. 1, pp. 49-54, 1996.
[109] M. Rossi, L. Magnoni, C. Miracco et al., “ $\beta$-catenin and Gli1 are prognostic markers in glioblastoma," Cancer Biology and Therapy, vol. 11, no. 8, pp. 753-761, 2011.

[110] D. Cui, Q. Xu, K. Wang, and X. Che, "Gli1 is a potential target for alleviating multidrug resistance of gliomas," Journal of the Neurological Sciences, vol. 288, no. 1-2, pp. 156-166, 2010.

[111] R. Senetta, C. Miracco, S. Lanzafame et al., "Epidermal growth factor receptor and caveolin-1 coexpression identifies adult supratentorial ependymomas with rapid unfavorable outcomes," Neuro-Oncology, vol. 13, no. 2, pp. 176-183, 2011.

[112] M. Sivaparvathi, R. Sawaya, S. W. Wang et al., "Overexpression and localization of cathepsin B during the progression of human gliomas," Clinical and Experimental Metastasis, vol. 13, no. 1, pp. 49-56, 1995.

[113] G. J. Kitange, B. L. Carlson, M. A. Schroeder et al., "Expression of CD74 in high grade gliomas: a potential role in temozolomide resistance," Journal of Neuro-Oncology, vol. 100, no. 2, pp. 177-186, 2010.

[114] L. J. Lewis-Tuffin, F. Rodriguez, C. Giannini et al., "Misregulated E-cadherin expression associated with an aggressive brain tumor phenotype," PLoS ONE, vol. 5, no. 10, Article ID e13665, 2010.

[115] J. Wykosky, D. M. Gibo, C. Stanton, and W. Debinski, "EphA2 as a novel molecular marker and target in glioblastoma multiforme," Molecular Cancer Research, vol. 3, no. 10, pp. 541-551, 2005.

[116] J. Wykosky, D. M. Gibo, C. Stanton, and W. Debinski, "Interleukin-13 receptor $\alpha 2$, EphA2, and Fos-related antigen 1 as molecular denominators of high-grade astrocytomas and specific targets for combinatorial therapy," Clinical Cancer Research, vol. 14, no. 1, pp. 199-208, 2008.

[117] H. D. Mennel and B. Lell, "Ganglioside (GD2) expression and intermediary filaments in astrocytic tumors," Clinical Neuropathology, vol. 24, no. 1, pp. 13-18, 2005.

[118] H. Yamamoto, J. Swoger, S. Greene et al., “ $\beta 1,6-\mathrm{N}$-acethylglucosamine-bearing N-glycans in human gliomas: implications for a role in regulating invasivity," Cancer Research, vol. 60, no. 1, pp. 134-142, 2000.

[119] O. Persson, L. G. Salford, J. Fransson, B. Widegren, C. A. K. Borrebaeck, and B. Holmqvist, "Distribution, cellular localization, and therapeutic potential of the tumor-associated antigen Ku70/80 in glioblastoma multiforme," Journal of Neuro-Oncology, vol. 97, no. 2, pp. 207-215, 2010.

[120] T. Elsir, A. Eriksson, A. Orrego, M. S. Lindström, and M. Nistér, "Expression of PROX1 is a common feature of highgrade malignant astrocytic gliomas," Journal of Neuropathology and Experimental Neurology, vol. 69, no. 2, pp. 129-138, 2010 .

[121] K. D. Geiger, S. Hendruschk, E. P. Rieber et al., “The prostate stem cell antigen represents a novel glioma-associated antigen," Oncology Reports, vol. 26, no. 1, pp. 13-21, 2011.

[122] M. Ferletta, L. Uhrbom, T. Olofsson, F. Pontén, and B. Westermark, "Sox10 has a broad expression pattern in gliomas and enhances platelet-derived growth factor-B-induced gliomagenesis," Molecular Cancer Research, vol. 5, no. 9, pp. 891-897, 2007.

[123] C. S. Gondi, S. S. Lakka, D. H. Dinh, W. C. Olivero, M. Gujrati, and J. S. Rao, "RNAi-mediated inhibition of cathepsin B and uPAR leads to decreased cell invasion, angiogenesis and tumor growth in gliomas," Oncogene, vol. 23, no. 52, pp. 8486-8496, 2004.

[124] G. G. Gomez and C. A. Kruse, "Mechanisms of malignant glioma immune resistance and sources of 
immunosuppression," Gene Therapy and Molecular Biology, vol. 10, no. 1, pp. 133-146, 2006.

[125] C. S. Cobbs, L. Harkins, M. Samanta et al., "Human cytomegalovirus infection and expression in human malignant glioma," Cancer Research, vol. 62, no. 12, pp. 3347-3350, 2002.

[126] R. M. Prins, T. F. Cloughesy, and L. M. Liau, "Cytomegalovirus immunity after vaccination with autologous glioblastoma lysate," New England Journal of Medicine, vol. 359, no. 5, pp. 539-541, 2008.

[127] D. A. Mitchell, W. Xie, R. Schmittling et al., "Sensitive detection of human cytomegalovirus in tumors and peripheral blood of patients diagnosed with glioblastoma," NeuroOncology, vol. 10, no. 1, pp. 10-18, 2008.

[128] L. Bao, K. Dunham, M. Stamer, K. M. Mulieri, and K. G. Lucas, "Expansion of cytomegalovirus pp65 and IE-1 specific cytotoxic $\mathrm{T}$ lymphocytes for cytomegalovirus-specific immunotherapy following allogeneic stem cell transplantation," Biology of Blood and Marrow Transplantation, vol. 14, no. 10, pp. 1156-1162, 2008.

[129] L. Bao, Q. Sun, and K. G. Lucas, "Rapid generation of CMV pp65-specific T cells for immunotherapy," Journal of Immunotherapy, vol. 30, no. 5, pp. 557-561, 2007.

[130] J. Yao, C. Bechter, M. Wiesneth et al., "Multimer staining of cytomegalovirus phosphoprotein 65 -specific T cells for diagnosis and therapeutic purposes: a comparative study," Clinical Infectious Diseases, vol. 46, no. 10, pp. e96-e105, 2008.

[131] A. Schmitt, T. Tonn, D. H. Busch et al., "Adoptive transfer and selective reconstitution of streptamer-selected cytomegalovirus-specific $\mathrm{CD}^{+} \mathrm{T}$ cells leads to virus clearance in patients after allogeneic peripheral blood stem cell transplantation," Transfusion, vol. 51, no. 3, pp. 591-599, 2011.

[132] J. D. Fontenot, J. P. Rasmussen, M. A. Gavin, and A. Y. Rudensky, "A function for interleukin 2 in Foxp3-expressing regulatory T cells," Nature Immunology, vol. 6, no. 11, pp. 1142-1151, 2005.

[133] A. El Andaloussi and M. S. Lesniak, "An increase in CD4+CD25+FOXP3+ regulatory T cells in tumor-infiltrating lymphocytes of human glioblastoma multiforme," $\mathrm{Neu}$ ro-Oncology, vol. 8, no. 3, pp. 234-243, 2006.

[134] P. E. Fecci, D. A. Mitchell, J. F. Whitesides et al., "Increased regulatory T-cell fraction amidst a diminished CD4 compartment explains cellular immune defects in patients with malignant glioma," Cancer Research, vol. 66, no. 6, pp. 32943302, 2006.

[135] A. B. Heimberger, M. Abou-Ghazal, C. Reina-Ortiz et al., "Incidence and prognostic impact of $\mathrm{FoxP}^{+}$regulatory $\mathrm{T}$ cells in human gliomas," Clinical Cancer Research, vol. 14, no. 16, pp. 5166-5172, 2008.

[136] F. Annunziato, L. Cosmi, F. Liotta, E. Maggi, and S. Romagnani, "The phenotype of human Th17 cells and their precursors, the cytokines that mediate their differentiation and the role of Th17 cells in inflammation," International Immunology, vol. 20, no. 11, pp. 1361-1368, 2008.

[137] Y. Y. Wan and R. A. Flave I I, "How diverse-CD4 effector T cells and their functions," Journal of Molecular Cell Biology, vol. 1, no. 1, pp. 20-36, 2009.

[138] P. Muranski, A. Boni, P. A. Antony et al., "Tumor-specific Th17-polarized cells eradicate large established melanoma," Blood, vol. 112, no. 2, pp. 362-373, 2008.

[139] D. A. Wainwright, S. Sengupta, Y. Han, I. V. Ulasov, and M. S. Lesniak, "The presence of IL-17A and T helper 17 cells in experimental mouse brain tumors and human gliom," PLoS ONE, vol. 5, no. 10, Article ID e15390, 2010.

[140] J. C. Rodrigues, G. C. Gonzalez, L. Zhang et al., "Normal human monocytes exposed to glioma cells acquire myeloidderived suppressor cell-like properties," Neuro-Oncology, vol. 12, no. 4, pp. 351-365, 2010.

[141] B. Raychaudhuri, P. Rayman, J. Ireland et al., "Myeloidderived suppressor cell accumulation and function in patients with newly diagnosed glioblastoma," Neuro-Oncology, vol. 13, no. 6, pp. 591-599, 2011.

[142] H. Ghebeh, M. M. Bakr, and S. Dermime, "Cancer stem cell immunotherapy: the right bullet for the right target," Hematology/Oncology and Stem Cell Therapy, vol. 1, no. 1, pp. $1-2,2008$.

[143] S. Bao, Q. Wu, R. E. McLendon et al., "Glioma stem cells promote radioresistance by preferential activation of the DNA damage response," Nature, vol. 444, no. 7120, pp. 756760, 2006.

[144] G. Liu, X. Yuan, Z. Zeng et al., "Analysis of gene expression and chemoresistance of $\mathrm{CD} 133^{+}$cancer stem cells in glioblastoma," Molecular Cancer, vol. 5, article 67, 2006.

[145] S. K. Singh, I. D. Clarke, M. Terasaki et al., "Identification of a cancer stem cell in human brain tumors," Cancer Research, vol. 63, no. 18, pp. 5821-5828, 2003.

[146] L. Prestegarden, A. Svendsen, J. Wang et al., "Glioma cell populations grouped by different cell type markers drive brain tumor growth," Cancer Research, vol. 70, no. 11, pp. 4274-4279, 2010.

[147] S. Pellegatta, P. L. Poliani, D. Corno et al., "Neurospheres enriched in cancer stem-like cells are highly effective in eliciting a dendritic cell-mediated immune response against malignant gliomas," Cancer Research, vol. 66, no. 21, pp. 1024710252, 2006.

[148] R. Wang, K. Chadalavada, J. Wilshire et al., "Glioblastoma stem-like cells give rise to tumour endothelium," Nature, vol. 468, no. 7325, pp. 829-835, 2010.

[149] L. Ricci-Vitiani, R. Pallini, M. Biffoni et al., "Tumour vascularization via endothelial differentiation of glioblastoma stem-like cells," Nature, vol. 468, no. 7325, pp. 824-830, 2010.

[150] R. A. Lake and B. W. S. Robinson, "Immunotherapy and chemotherapy—apractical partnership," Nature Reviews Cancer, vol. 5, no. 5, pp. 397-405, 2005.

[151] C. Bourquin, S. Schreiber, S. Beck, G. Hartmann, and S. Endres, "Immunotherapy with dendritic cells and CpG oligonucleotides can be combined with chemotherapy without loss of efficacy in a mouse model of colon cancer," International Journal of Cancer, vol. 118, no. 11, pp. 2790-2795, 2006.

[152] C. H. Kim, S. J. Woo, J. S. Park et al., "Enhanced antitumour immunity by combined use of temozolomide and TAT-survivin pulsed dendritic cells in a murine glioma," Immunology, vol. 122, no. 4, pp. 615-622, 2007.

[153] X. Xu, F. Stockhammer, A. Schmitt et al., "Therapeutical doses of temozolomide do not impair the function of dendritic cells and $\mathrm{CD}^{+} \mathrm{T}$ cells," International Journal of Oncology, vol. 40, no. 3, pp. 764-772. 


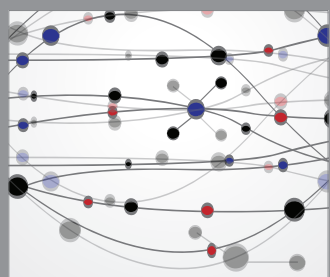

The Scientific World Journal
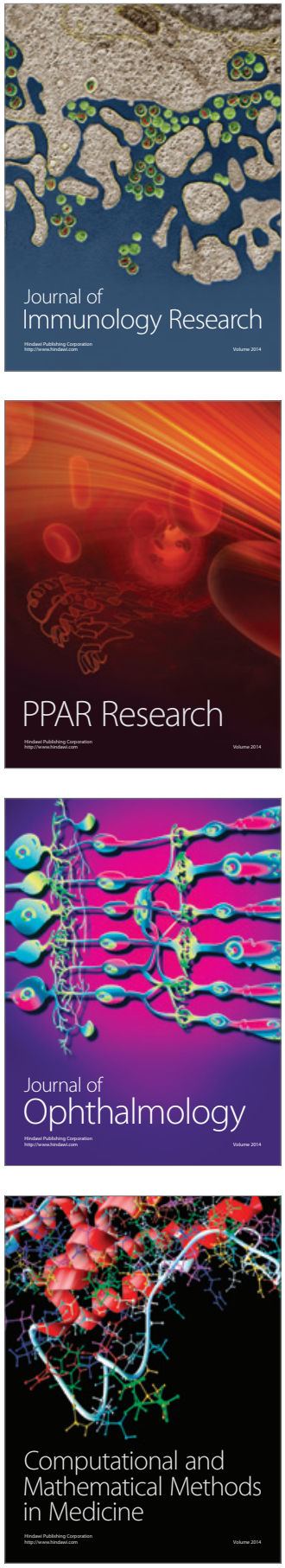

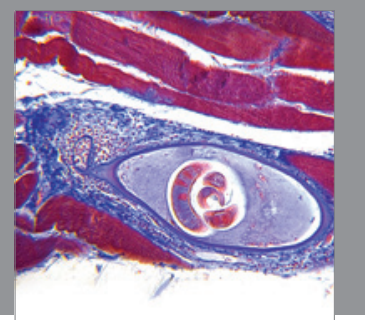

Gastroenterology

Research and Practice
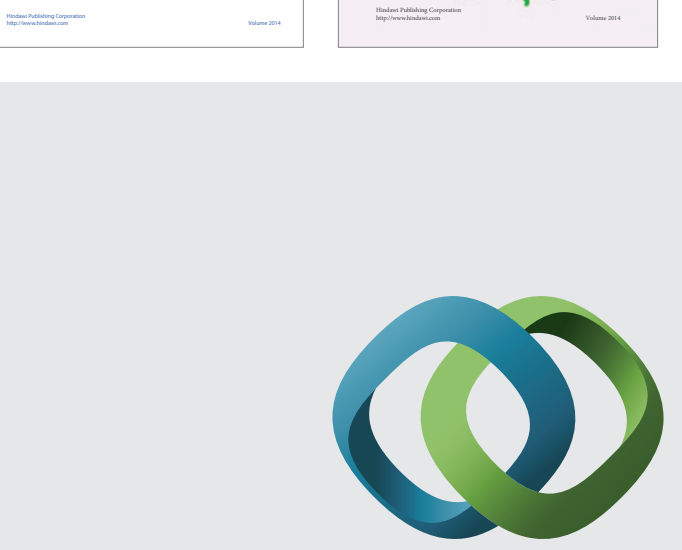

\section{Hindawi}

Submit your manuscripts at

http://www.hindawi.com
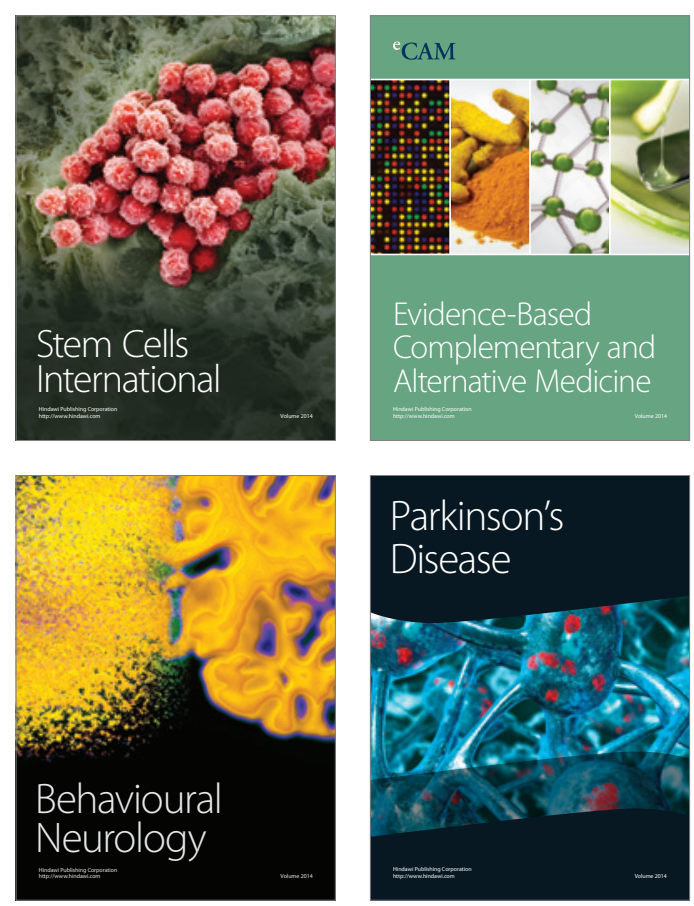

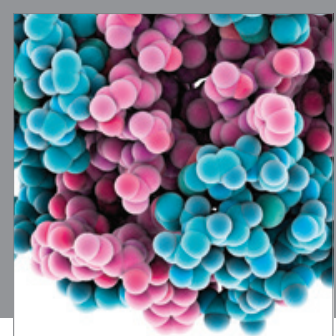

Journal of
Diabetes Research

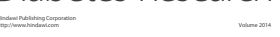

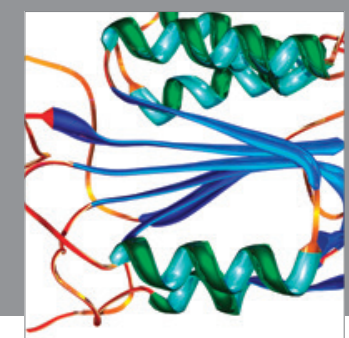

Disease Markers
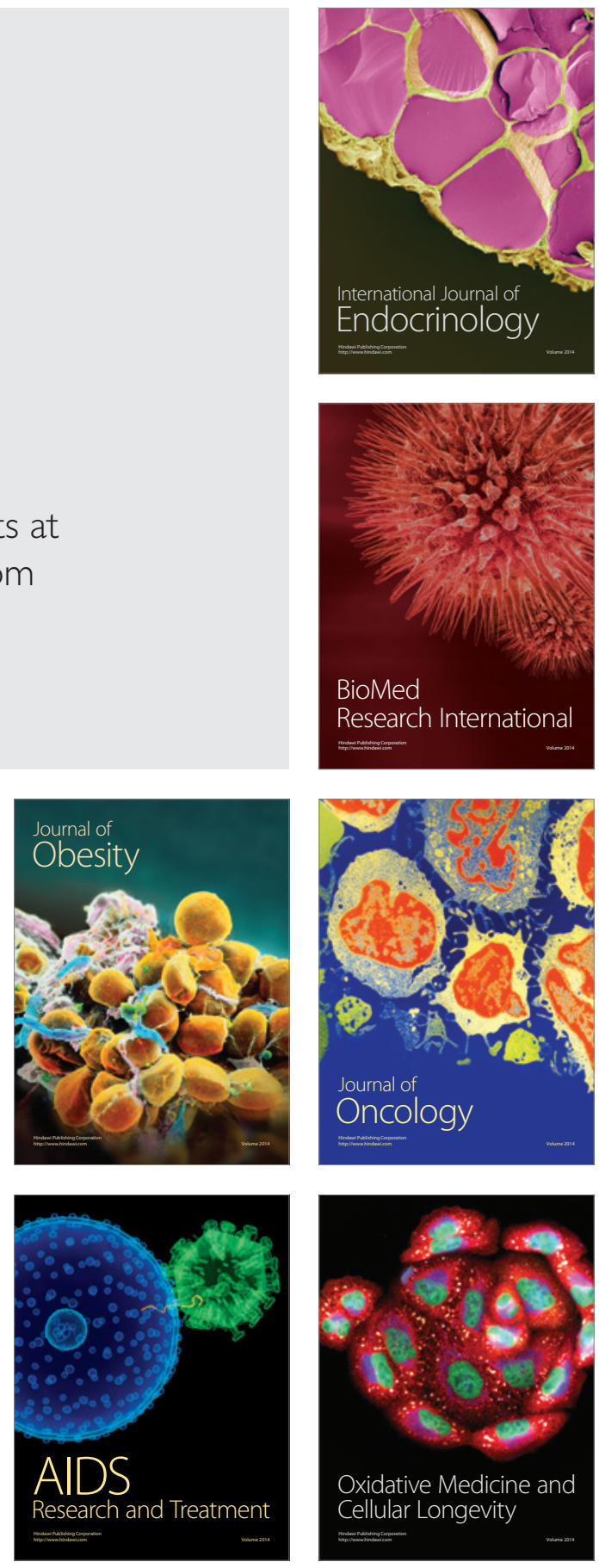